\title{
Bodies That Cannot Listen
}

\author{
Livia Jiménez Sedano
}

\begin{abstract}
This is a brief reflection on the consequences of the commodification of dance cultures from the former colonised world and the ways they are consumed in Europe. Inspired from ten years of fieldwork, the ethnic structuring of postcolonial dance floors in European cities proves an empirical basis to start this line of thought. Instead of promoting respect and interest in the dance forms and the cultural contexts in which these dance forms developed, aficionados tend to consider that these are less evolved, beautiful and interesting than the appropriations they develop in their home countries. As a result, commodification leads to reinforcing previous stereotypes and emic hierarchies of value. The kinetic metaphor of the bodies that scream but cannot listen structures the text and its arguments.
\end{abstract}

\section{KEYWORDS}

embodiment, ethnomusicology, Europeanness, kizomba dance

Throughout the last ten years of fieldwork in social dance contexts in Southern Europe I have witnessed in astonishment how European aficionados who enrol in 'world dances' courses very often considered their own kinetic capacities as superior to those whose cultures they supposedly try to reproduce. 'Have you ever seen Dominicans dancing Bachata? They cannot dance properly', a girl stated in a Bachata workshop in Madrid, with a 'yeah, you're right' reply from the teacher. 'You know what? Moroccan women cannot dance', commented a belly-dance student with her instructor after a summer trip in Morocco. 'Africans remained stacked in the basic step. We Europeans are the ones who have made Kizomba evolve', stated a Kizomba teacher in Portugal, expressing aloud a widely shared idea among the transnational community of European aficionados.

From my point of view, these statements are not just a random sample of decontextualised pieces of speech; instead, they make explicit what constitutes the structural set of evolutionist representations upon which the 'world dances' industries are established and developed in Europe. Their success relies on their echoing of postcolonial stereotypes that still work in the social imaginary of middle-class consumers in postcolonial Europe. The scientific invention of primitive society 
(Kuper 1988) led to the evolutionism paradigm and the feelings of moral superiority attached to it. Even though we have supposedly moved beyond these ideas and they are not usually expressed verbally, they are still danced every night in clubs all over Europe. What Gerd Baumann (2004) called 'orientalist grammar of identity/alterity' is embodied and transformed into fun, leisure, lifestyle, addiction, self-fashioning art.

The first characteristic of European dancing bodies is what we may call a voracious habitus (Bourdieu 1989). Dance aficionados are usually voracious in their learning of a wide variety of dances. Dance school managers are aware of it and foster this insatiable appetite, offering 'open pass' options in which students can jump from a flamenco lesson to a tango workshop, do some Bollywood and hip-hop before trying some Kizomba, samba and salsa. In the context of salsa, Bachata and Kizomba festivals, it is rather usual to see the anxiety in the eyes of learners looking at the timetables exposed at the entrance. They need to decide among five workshops that run at the same time, while they would love to take them all and not miss opportunities for consuming more and more steps and figures. This voracity, which fuels the expansion of the 'world dances' market, relies on the deep conviction that European cosmopolitan bodies are incredibly flexible and can easily embody many diverse kinetic cultures. In other words, their cosmopolitan habitus is open, flexible and prepared for limitless expansion, in contrast with the more constrained habitus of those they emulate, who stay stacked in endless repetition of 'basic steps'. Virtuosity, acrobatic figures, fast changes and endless repertoire are regarded as synonymous with 'high level' and evolution. On the contrary, repetition, slowness, concentration and high specialisation in a limited set of movements, which dance scholar Yvonne Daniel (2002) portrays as characteristic of 'dancing wisdom', are considered 'low level' traits in this context.

Commodification proves a process through which complex kinetic cultures are reduced to entertainment products apt for consumption. The dimensions of those dances as repositories of knowledge (Daniel 2002), political tools (Browning 1995 Giurchescu 2001; Quintero 2009), systems of relation (Grau 1998) and communication (Hanna 1979) are ignored in the 'world dances' market. In this way, they are decontextualised, simplified (Savigliano 1995), depoliticised (Robinson 2010), resignified in a new context of practices as well as rationalised and hygienitised (Hutchinson 2014), stereotyped (McMains 2016), broken into pieces and forged with other elements alien to its 
ethos (Robinson 2010). Otherwise, potential consumers would perceive that they are dealing with hard issues that need a humble and patient attitude. Only a long-term socialisation with the dancing social group - sharing all the daily experiences that they symbolise through movement - would lead to a minimum level of inner understanding of the kinetic culture. As a consequence, the embodiment process would take long years of effort, and the dance studio would not be considered the appropriate context to learn. In other words, it would prevent potential learners from even trying it, and the industry would enter bankruptcy.

In the real world many students feel able to become teachers after one or two years of learning one of these 'easy' world dances. In this ethos, these funny dances are not comparable to high-culture European ballet or competitive British ballroom, which involve a greater investment of time, money and energy. The lower respectability of 'world dances' often relates to the sexual connotations ascribed to them, usually connected to their African ancestry (Quintero 2009; Travassos 2004). From this evolutionist point of view, they cannot keep up with the 'cleaner', 'more difficult' and 'more developed' European institutionalised dances. In fact, one of the aims of the passionate aficionados of 'world dances' is to operate changes on their beloved dance form so as to make it 'evolve'. In this way, the ballroomisation of salsa, samba, Kizomba, Rumba and so on turns the 'raw' into the 'cooked', the 'vulgar' into the 'glamorous', the 'basic' into the 'evolved'.

Finally, we may wonder what leads all these European dancing crowds to 'world dances' schools, events and festivals. If their wish was 'getting in contact with other cultures', as they usually assert when we ask them, they would just visit the spaces in which immigrants from the former colonies gather to dance. This applies especially to genres that are learned through socialisation, such as salsa, Bachata or Kizomba. Nevertheless, the existing empirical evidence points to the opposite direction: dance aficionados systematically avoid salsa places frequented by Latinos (Llano 2018) and African discos when they want to dance Kizomba (Jiménez 2018); indeed, the very existence of these global dance industries makes sense just because they refuse to learn through direct socialisation in its original context. Inter-ethnic tensions and the anxieties involved in embodying the 'other' prevent them from even trying. Hence, it seems that the motivation for this dance consumerism lies somewhere else. According to David Le Breton (1990), the body has come to substitute symbolically the solid 
social relations that have dissolved in late modernity, what Zygmunt Bauman (2000) called 'liquid modernity'. In this way, the body has turned into an alter ego, a partner to take care of, discover and expand for reaching personal transcendence. This anxious individual journey to display the body in all its possible dimensions encourages middleclass Europeans to travel around the world through their own bodies in motion, discovering new ways of moving it, feeling it, experiencing it. The voracious habitus of European dancing bodies does not constitute a movement towards the other but rather towards the empty self. 'World dances' aficionados trust in the capacity of others' dances to turn their social suffering into joy, a shift from 'tristeza' to 'alegría' through dancing practices (Kabir 2018), as it happened with enslaved people in colonial times. However, they are not able to just learn and consciously embody other cultures' knowledge. They get bored easily and ask for new steps, new acrobatic movements, pushing the body to its limits, expanding its possibilities - that is, 'making the dance evolve'. These Orientalised embodied representations are displayed in Europe's every night life (Delgado and Muñoz 1997). European 'world dances' aficionados do not just dance because they like it; they dance because they need it. European dancing bodies cannot remain silent and let other kinetic cultures' messages reach them because this silence would force them to confront their own emptiness and anxieties. European dancing bodies scream on the dance floor, but they don't listen.

Livia Jiménez Sedano, National Distance Education University. E-mail: liviajs@fsof.uned.es

\section{References}

Bauman, Z. (2000), Liquid Modernity (Cambridge: Polity).

Baumann, G. (2004), 'Grammars of Identity/Alterity: A Structural Approach', in G. Baumann and A. Gingrich (eds.), Grammars of Identity/Alterity (New York: Berghahn), 18-50.

Bourdieu, P. (1989), 'Social Space and Symbolic Power' Sociological Theory 7, no. 1: 14-25.

Browning, B. (1995), Samba: Resistance in Motion (Oxford: Westview Press).

Daniel, Y. (2002), Dancing Knowledge: Embodied Knowledge in Haitian Voudou, Cuban Yoruba and Bahian Candomblé (Champaign: University of Illinois Press). 
Delgado, C. F. and J. E. Muñoz (1997), Everynight Life: Culture and Dance in Latin/o America (Durham, NC: Duke University Press).

Giurchescu, A. (2001), 'The Power of Dance and Its Social and Political Uses', Yearbook for Traditional Music 33: 109-122.

Grau, A. (1998), 'On the Acquisition of Knowledge: Teaching Kinship through the Body among the Tiwi of Northern Australia', in V. Keck (ed.), Common Worlds and Single Lives (Oxford: Berg), 71-93.

Hanna, J. L. (1979), To Dance Is Human: A Theory of Nonverbal Communication (Austin: University of Texas Press).

Hutchinson, S. (2014), 'Dancing in Place: An Introduction', in S. Hutchinson (ed.), Salsa World (Philadelphia, PA: Temple University Press).

Jiménez, L. (2018), 'Ritual Roles of “African nights” DJs in Lisbon', Cadernos de Arte e Antropologia 7, no. 1: 15-26.

Kabir, A.J. (2018), 'Afro-Latin-Africa. Movement and Memory in Benin', in M. Hawas (ed.), The Routledge Companion to World Literature and World History (London: Routledge), 234-245.

Kuper, A. (1988), The Invention of Primitive Society: Transformations of an Illusion (London: Routledge).

Le Breton, D. (1990), Anthropologie du Corps et Modernité (Paris: PUF).

Llano, I. (2018), 'Symbolic Struggles on the Dance Floor in Barcelona: Cultural Identities and Different Experiences of Salsa Dancing', in J. Martí and S. Revilla (eds.), Making Music, Making Society (Cambridge: Cambridge Scholars), 138-166.

McMains, J. (2016), “"Hot” Latin Dance: Ethnic Identity and Stereotype', in A. Shay and B. Sellers-Young (eds.), The Oxford Handbook of Dance and Ethnicity (Oxford: Oxford University Press), 480-500.

Quintero, A. (2009), Cuerpo y Cultura. Las Músicas 'Mulatas' y la Subversión del Baile (Madrid: Iberoamericana).

Robinson, D. (2010), 'The Ugly Duckling: The Refinement of Ragtime Dancing and the Mass Production and Marketing of Modern Social Dances', Dance Research 28, no. 2: 179-199.

Savigliano, M. (1995), Tango and the Political Economy of Passion (Oxford: Westview Press).

Travassos, E. (2004), 'Por uma Cartografia Ampliada das Danças de Umbigada', in J. M. Pais, J. P. de Brito and M. V. de Carvalho (eds/), Sonoridades Luso-AfroBrasileiras, (Lisboa: Imprensa de Ciências Sociais), 227-253. 